\title{
A Study of the Poetic Foundations of Three Prominent Contemporary Poets Mehdi Akhavan Sales, Ahmad Shamloo and Hamid Mossadegh with an Approach to European Literature
}

Un estudio de los fundamentos poéticos de tres destacados poetas contemporáneos Mehdi Akhavan Sales, Ahmad Shamloo y Hamid Mossadegh con un enfoque de la literatura europea

Farshad Daneshvar Nike

Department of Persian Language and Literature, Faculty of Humanities, Mashhad branch, Islamic Azad University, Mashhad, Iran ORCID: 0000-0002-4727-8662

Mohammad Fazeli*

Department of Persian Language and Literature, Faculty of Humanities, Mashhad Branch, Islamic Azad University, Mashhad, Iran ORCID: 0000-0002-7865-1984

Parvindokht Mashhonr

Department of Persian Language and Literature, Faculty of Humanities, Mashhad Branch, Islamic Azad University, Mashhad, Iran ORCID: 0000-0002-6293-6002

*Correspondence

Email: drmohammadfazelidr@gmail.com
Cite as:

Daneshvar, F., Fazali, M., \& Dokht, P. (2021). A Study of the Poetic Foundations of Three Prominent Contemporary Poets Mehdi Akhavan Sales, Ahmad Shamloo and Hamid Mossadegh with an Approach to European Literature. Propósitos y Representaciones, 9(SPE3), e1097. Doi: http://dx.doi.org/10.20511/pyr2021.v9nSPE3.1097 


\section{Summary}

Literary schools in the West are influenced by the social and political conditions prevailing in those societies; This means that each school in line with the political and social developments of its time has undergone structural and content changes and gives way to a school with a different perspective. In the second half of the sixteenth century, medieval civilization collapsed and underwent many social, political, and religious changes. The group of many high-ranking landowners and feudal lords who had been forced to pay large sums of money as a result of the successive defeats of France in the Hundred Years' War were gradually forced to sell their lands and properties with all legal rights. The tribal kings belonged to it. This caused the landowners to lose their influence and power, and the government to change from a form of sectarian monarchy to an absolute monarchy. The king, like the ancient Romans, was considered to have absolute authority in the administration of the affairs of the country, and the lords of all lands served the king. By order of the Shah, ministries, the army, the Court of Accounts and the judiciary were formed; The bourgeoisie, meanwhile, entered government positions because of the prosperity of the commercial and industrial market, the wealthy and influential. Other important events, such as new inventions, new naval discoveries, as well as wars known as the Italian Wars, all went hand in hand and completely changed the way of life and the situation of French society. With the advent of Luther and Calvin and fundamental religious reforms, popular belief in the teachings of the clergy waned, and since then Christianity has been limited to a set of rites and ceremonies held by Catholic priests. In addition, Christian theologians gradually found themselves without the need for direct reference to Christian scriptures and recklessly discussed religious issues. On the other hand, in literary works, the desire for great ideas disappeared and literature, which was based on spiritual favors, became frozen. Religious plays lost their religious and heavenly appeal and took on the color of hypocrisy and trade; In this way, almost all the systems and laws that ruled France for centuries were questioned at the beginning of this century, and fundamental changes took place in Europe at that time; But it was not long before the great scientific and maritime discoveries showed him the power of human thought and greatness, and showed him that human endeavors must expand without borders, and that in a world full of contradictions and contradictions, he is free to go his own way. Choose. From then on, people liked what they thought was beautiful and charming; Therefore, not only the manifestations of the world of sensations and the world of nature were in the center of attention, but also the literary works of ancient writers and poets, especially ancient Greece, were doubly valued by them. This gradually led to the formation of a new attitude.

Keywords: European Literature, Third Brotherhood, Shamloo, Mossadegh

\section{Resumen}

Las escuelas literarias de Occidente están influenciadas por las condiciones sociales y políticas que prevalecen en esas sociedades; Esto significa que cada escuela en consonancia con la evolución política y social de su época ha sufrido cambios estructurales y de contenido y da paso a una escuela con una perspectiva diferente. En la segunda mitad del siglo XVI, la civilización medieval se derrumbó y sufrió muchos cambios sociales, políticos y religiosos. El grupo de muchos terratenientes de alto rango y señores feudales que se habían visto obligados a pagar grandes sumas de dinero como consecuencia de las sucesivas derrotas de Francia en la Guerra de los Cien Años se vieron obligados gradualmente a vender sus tierras y propiedades con todos los derechos legales. Los reyes tribales le pertenecían. Esto hizo que los terratenientes perdieran su influencia y poder, y que el gobierno cambiara de una forma de monarquía sectaria a una monarquía absoluta. Se consideraba que el rey, como los antiguos romanos, tenía autoridad absoluta en la administración de los asuntos del país, y los señores de todas las tierras servían al rey. Por orden del Sha, se formaron los ministerios, el ejército, el Tribunal de Cuentas y el poder judicial; La burguesía, mientras tanto, entró en puestos de gobierno debido a la 
prosperidad del mercado comercial e industrial, los ricos e influyentes. Otros acontecimientos importantes, como los nuevos inventos, los nuevos descubrimientos navales, así como las guerras conocidas como las Guerras de Italia, fueron de la mano y cambiaron por completo la forma de vida y la situación de la sociedad francesa. Con la llegada de Lutero y Calvino y las reformas religiosas fundamentales, la creencia popular en las enseñanzas del clero se desvaneció $\mathrm{y}$, desde entonces, el cristianismo se ha limitado a un conjunto de ritos y ceremonias celebrados por sacerdotes católicos. Además, los teólogos cristianos se encontraron gradualmente sin la necesidad de una referencia directa a las escrituras cristianas y discutieron imprudentemente temas religiosos. Por otro lado, en las obras literarias, el deseo de grandes ideas desapareció y la literatura, que se basaba en favores espirituales, se congeló. Las obras religiosas perdieron su atractivo religioso y celestial y tomaron el color de la hipocresía y el comercio; De esta manera, casi todos los sistemas y leyes que gobernaron Francia durante siglos fueron cuestionados a principios de este siglo, y se produjeron cambios fundamentales en Europa en ese momento; Pero no pasó mucho tiempo antes de que los grandes descubrimientos científicos y marítimos le mostraran el poder del pensamiento y la grandeza humanos, y le mostraran que los esfuerzos humanos deben expandirse sin fronteras, y que en un mundo lleno de contradicciones y contradicciones, él es libre de seguir su camino. Propia manera. Escoger. A partir de entonces, a la gente le gustó lo que pensaba que era hermoso y encantador; Por lo tanto, no solo las manifestaciones del mundo de las sensaciones y el mundo de la naturaleza estaban en el centro de atención, sino que también las obras literarias de escritores y poetas antiguos, especialmente la antigua Grecia, fueron doblemente valoradas por ellos. Esto condujo gradualmente a la formación de una nueva actitud.

Palabras clave: Literatura europea, Tercera Hermandad, Shamloo, Mossadegh

\section{Developments of contemporary Persian poetry}

Contemporary Persian poetry entered the field of Persian language and literature with a new structure in order to express the content of the new era. In this type of poetry, the form of prosody, the balance of lines, the dominance of rhyme over the composition and theme of the verse were lost and a kind of pronoun was created in which liberation is considered in terms of equality of verbs and a new type of ending of lines or parts. And it causes a change in the way of dealing with the language of poetry, syntactic changes to the composition of lines and the horizontal and vertical relationship of words and concepts in rhythmic poetry. The most successful of these poems, which had a definite and codified style, first appeared in the poems of Nima Yoshij, which, of course, was inspired by Western poetry. After him, poets such as Ahmad Shamloo, Mehdi Akhavan Sales, Forough Farrokhzad, Sohrab Sepehri, Hamid Mossadegh, etc. continued this path and by using the view, perspective, poetic feeling and applying the rules of European literary schools to They revived contemporary poetry and followed in their prose the prose poetry that began in the 17th and 18th centuries in Europe with the works of Charles Baudelaire and was perfected by Arthur Rambo, Stephen Mallarmé, and so on.

These great poets learned the rules and style of schools such as classicism, romanticism, etc., and adapted them to the different capacities and dimensions of the Persian language, and with a cross-border expression and a universal view, they distinguished it and thus, what From the feelings and objects that they saw as necessary for their poetry, they introduced it in contemporary poetry to establish a unique language and a special style that later found many followers. Their new look at topics such as the earthly lover, individual issues, social orientations and concepts such as equality, freedom, homeland, etc. through the lens of modern European schools to the world around them caused their poetry to be rich and credible. Enjoy twice as much.

But the phenomenon of "new poetry" in Iran, as in other parts of the world, was the result of a sudden encounter with the waves of modernity that from the 15th and 16th centuries with the advent of the Renaissance, the collapse of medieval thought and the prevalence of "science- 
oriented" and "humanism" It started from the west of the earth and gradually covered the world. This great historical change, which is a new chapter in the history of human life, led to fundamental changes in the structure of contemporary human life by claiming modern rationality. This phenomenon in Iran through M. The old economic and social foundations were laid. On the one hand, the capitalist countries turned to these countries in order to expand their colonial influence in the rich but backward lands (including Iran) and to have their rich resources, and on the other hand, the defeat of Iran in long wars with Russia. , Revealed the depth of the country's backwardness and convinced the people that the most vital need of the country is to equip itself with the intellectual achievements and technology of the West; Therefore, with the increase of British and Russian influence, and the conclusion of agreements and the transfer of various concessions to these two countries, the necessary ground was prepared for the emergence of social-protest movements and finally the constitutional movement.

The Constitutional Revolution is one of the important factors in creating social, political and especially cultural changes in the history of Iran. Among the most important reasons for changes and developments in this period can be:

1- Sending students abroad, which had been practiced since the time of Abbas Mirza, getting acquainted with the culture of the West by learning French languages and reading and translating books and newspapers in Western, Turkish (Ottoman) and Arabic (Egyptian) 2Writing articles in Persian and Turkish by Caucasian Iranians (who were now part of Russia) in order to awaken their compatriots. 3- Iqbal from some of the leading Egyptian newspapers in Iran 4- Establishment of teahouses and newspapers in Iran and printing and publishing books and Translation of cultural books 5- Establishment of new schools, especially Dar al-Fonun University and the arrival of French teachers in Iran 6- The arrival of the breeze of global modernity in Iran 7- Establishment of constitutional system and establishment of parliament and people's participation in the country's destiny and establishment of laws 8- Familiarization of people with New social, philosophical and legal concepts and terms such as nation, freedom, party, law, enlightenment, tyranny, constitution, parliament, etc. 10 - مالوف و ... People travel to the Ottoman Empire, India and Western countries. (Shamisa, 1374: 340 - 339)

In this way, the influence of Western culture and civilization in the social and intellectual life of Iranians, caused great cultural changes, which, of course, was not free of excesses.

Dr. Javad Mojabi believes: "In countries that have a strong cultural tradition and a long history, innovation is difficult and slow and always threatens to deviate in its direction. Our one hundred-year-old modernity is always exposed to extremes. And there have been historical and cultural deviations.

Throughout the history of our literature and art, the formal and content structure of prose and miniature poetry has been so prevalent in particular and general artistic tastes that it seems absolute perfection, and the possibility of creating beauty and art seemed impossible except in conventional and traditional forms. As small changes in the appearance or type of ode, lyric and Masnavi or mural and book were always done within the framework of ancient and inviolable contracts. "On the eve of the constitutional revolution, with the emergence of doubts in many social and political structures, the possibility of change in traditional forms, including common literary forms, is raised." (Mojabi, 2002: 75) In such a way that despite many other intellectual and cultural barriers, literature can not keep away from the impact of social developments. Familiarity with the cultural manifestations of the West such as poetry, storytelling, literary criticism, etc., along with the emergence of revolutionary and individual movements, provides the basis for the emergence of fundamental changes in its body and literature becomes popular in the true sense for the first time; Numerous groups become acquainted with the revolutionary literature of their time through newspapers; Poets use their poetry in the service of political and social issues, and although they do not create a significant change in terms of literature, they 
prepare the ground for the emergence of new poetry in later periods by creating a change in content and thought.

In this period, "linguistically", the common language of all understandings of the same era is used and Persian words find a significant presence in the poetry of poets. Intellectually, the idea that poetry should only deal with certain subjects such as love, mysticism, praise, and satire disappears, and special attention is paid to social and political issues and current issues in poetry. Attention to ancient Iran, women's liberation, hatred of dictatorship, passion for modernity and revival are common themes in the poetry of this period. "From a literary point of view, poets no longer pay much attention to the literary industry, and often express their words in clear and unpretentious language." (Shamisa, 1373: 341 - 340)

Familiarity with modern Western culture and literature encouraged poets of the period to use two new sources: Ottoman poetry and modern French poetry. These sources gradually influenced the intellectual, stylistic and aesthetic criteria in Persian poetry, causing literature to no longer preach science, philosophy, ethics and religion and to focus all its efforts on arousing the feeling and promoting the aesthetic understanding of its audience. "There were issues in a society that was excited and familiar with world culture, which necessitated a fundamental change in social, cultural and political structures and concepts. "Researchers and creators of works of art, in response to this inner need of society, sought a new language and expression appropriate to this space, and hence, various experiences took place by them." (Mojabi, 1381: 75) These experiences did not present formatting and did not talk about new topics, but showed new views that, if original, would be manifested in the awe of a new language that consists of words and combinations. From syntax to simile, it included pseudonyms, metaphors, and metaphors.

Nima's humanistic poetry is not a praise of human morality and attributes, but an expression of his challenging material and spiritual life in this world, which has taken place as an artistic creation in the field of language and connects the destiny of man and the world. In this poem, the direct relationship between man and the universe around him is the purpose and motivation of creation The work is placed so that the intermediary poetry is committed to the universal content and format that human beings in every corner of this world, on the occasion of their biological, cultural and climatic necessities, give it a local-global color.

Hence, Nima's poetry can be considered the result of modernist efforts that "belong to the intellectual atmosphere that was formed with the constitutional movement in Iran and continued more or less until September 1320, the end of Reza Shah's era. . At this time, Iranian intellectuals are still under the influence of an idea that originated in European liberalism and whose most fundamental concept is political freedom. "This intellectual also carries the ideas of the European Enlightenment, and he has been inspired by the ideas of modern science and its concepts and worldview." (Assyrian, 1998: 77)

In this regard, Nima tries to change the conventional principles of poetry by reviewing its traditional attitude, which was based on fixed and inflexible rules such as rhythmic and muffled speech, certain poetry format, common literary language and predetermined meaning. In his view, "a poem is neither weight nor rhyme. Weight and rhyme are tools in the poet's hands; These are not in the line of idioms and heard topics. Such a method is like a scaffold for the relevant work. A poem is a means of expressing, influencing, and highlighting the innate experience and analyzing and interpreting his inner mysteries and differences. "Weight" is honestly mixed with the nature of poetry and changes with the poet's moods. "He says that presenting poetry in this new format is much more difficult than presenting it in its old form, which reduces its impact and influence." (Jalali, 1372: 334)

In other words, Nima accepts rhyme in poetry only in proportion to the musical atmosphere of the poem and considers its repetition and regular sequence insignificant because he believes that it limits the poet's mind and language and gives the poem an artificial state. Nima's view of 
poetry gives rise to a kind of "poetic individuality" in which the poet, relying on personal experiences and partiality, frees himself from the bottleneck of old poetic stereotypes and the main difference between traditional and modern poetry is the liberation of poetry from It establishes "single meaning". Beyond the transfer of meaning, he intends to create a new world of words, images and colors, thereby removing the ambiguity of existence from the reader's point of view, and in this regard, with the influence of European poets such as Rambo, Verlaine, Mallarmé, etc. He admits that he makes symbolic expression the main pillar of his poetry.

However, with the innovations that Nima created in the structure and content of Persian poetry, he started a movement that later paved the way for the emergence of various other currents and the path of Persian poetry was forever changed, both in terms of structure and content. Appeared. Here, while dealing with the flow of modern poetry, we also consider the currents that result from it.

\section{Poetic currents in Iran}

Basically, the flow of poetry does not have the totality and integrity of the school, although in the beginning it came from the same school views. In other words, sometimes several currents can be considered as branches of a large literary school that is still active. Therefore, the term "stream" is used only in reference to the various tendencies and branches in contemporary Iranian poetry and literature, and not to the established poetic styles of traditional Persian poetry or European literary schools.

The first currents of poetry were attributed to educated scholars and political intellectuals who, in addition to political dissent and belief in the need for change in the intellectual content and themes of poetry, also had a kind of prejudice and commitment to literary traditions in them, so that the present They did not learn the glorious and tough language of traditional Persian poetry. This movement, later known as the "traditional half", believed in traditionalism in form and modernity in the content of poetry. Representatives of this movement include: Adib al-Mamalik Farahani, Vahid Dastgerdi, Iraj Mirza, Malek al-Sho'arai Bahar and Ali Akbar Dehkhoda.

After this current of poetry, another current began to form as a result of the Constitutional Revolution, which, unlike the previous current of poetry, was not academically literate and was not very familiar with classical poetry and literature. This caused its poets not to be very obsessive and cautious in breaking literary traditions. This group played an important role in awakening the people and also providing the necessary ground for Nima Yoshij's literary revolution. The most famous figures of this movement are: Mirzadeh Eshghi, Seyyed Ashraf alDin Hosseini Gilani known as "Nasim Shomal", Aref Qazvini, Mohammad Farokhi Yazdi and Mirzadeh Eshghi, the poetic current of those who are called "constitutional reformers" The fame was based on modernity in form and content.

At the same time, other emerging poets such as Taghi Rafat, Shams Kasmaei, Jafar Khamenei, and Abolghasem Elhami (alias Lahouti) focused on the Constitutional Revolution, for the first time gaining experiences, albeit crude, in European free poetry. Their poetry was the beating heart of the poetry of the constitutional era and caused these people to become the first founders of modern poetry in Iran due to their breaking with tradition.

Mojabi believes: "Today's Iranian poetry has two serious beginners, Nima and Shamloo. Poetry changed once with Nima and again with A. It changed in the morning. Although Nima is the opener of today's Iranian poetry, but by maintaining a certain weight and rhyme, he maintained his old literature. a. Although Bamdad historically follows him and works for him for a while, but a little later, he finds it necessary to free the poem from the traditional constraints of the weight of the prosody and its consequences, and also deviates from the half-pronouns. "It legitimizes and regulates the experience of white poetry." (Mojabi, ibid .: 74)

Shamloo as the most prominent figure in Persian prose poetry, before getting acquainted with classical poetry Farsi gets acquainted with the works of European symbolists and surrealists 
such as Paul Alvar, Louis Aragon, Gabriel Garcia Lorca, Maya Kovsky, etc., and after that he eagerly influences Nima and uses Nima's language and look in "Song". "Forgotten" follows. "System 23" and then "Resolution" reflect the national and patriotic feeling in his social expression, and "Irons and Emotions" form the concerns and questions of the poet and indicate the beginning of an epic expression in contemporary poetry. has it. But Shamloo can be seen as a modern and contemporary poet in the "Fresh Air" collection. This is where the poet "chooses his path among the poets of French (Alvar), Russian (Mayakovsky), Spanish (Neruda and Lorca) and the language of the street and the market, and wants to separate himself from his past and that of his contemporaries." "And reach rebellion and revolt." (Sahib Ekhtiari and Baqerzadeh, 1381: 519) Under the influence of Nima and some Western poets, he tries to depict accurately and coherently what he has seen from an object in nature around him and his mental states in the face of inanimate objects. The curtain expresses. This descriptive power, created by the influence of the modern Western attitude, first directs him to natural elements such as mountains, forests, deserts, beaches, boats, and sailors, and later to urban elements, leading him to Unparalleled accuracy and sometimes harsh tone, put everything in front of the audience. Thus, he takes a big step towards updating the poem written by Nima. In fact, he brings poetry closer to today's life and makes it the language of the human condition.

More than Nima, he takes a stand against the followers of imitation of the style and form of the past and attacks the supporters of the school of classicism. In his view, today's poet should not see life in the worn-out form of yesterday, that is, the poet should not forget his literary responsibility to the history of literature and his social responsibility to society; Rather, it must actually intervene in the course of social affairs and be the pioneer and leader of its community in this field. He is "a poet who does not rely on literature in terms of words, but chooses his words directly from the language of the people of his community, and for this reason he is the richest and most powerful in using the language of today, and with his emergence the period "A new beginning begins in Persian poetry." (Ibid: 219-205)

Although Shamlou had started with Nimai's poems, he later considered Nimai's weight as an obstacle to the free movement of poetic thought and emotion and turned to a kind of melodic prose, and by defining a principled structure for this type of poetry, called it "poetry" "White" stabilized. The white poem that Westerners refer to as "Vers libre". It appeared in the poetry of 16th century English poets, culminating in the works of Sarry and Shakespeare's plays, as well as Milton's Paradise Lost. The weight of white poetry in Iambic English is five bases, which is closer to the normal weight of this language than other weights. Blank refers to the emptiness of rhyme in this type of poem. In Persian, it refers to a poem that has no weight or rhyme. "White poetry of weight and rhyme" of makeup and trimming may not feel needless; But he is deprived of it, and he may not be deprived of it. But he pretends to be needless, as if he has been tortured upside down, who deliberately wants to stay naked so that the eyes of the spectators can see the scars of torture on his body and find out the secret of his head down. In the form of "poetry". A poem that asks for its colorless form - its mental and abstract form - to "become" and to become action. Shows alienation and impatience with anything extra, with every rhyme. He is stubborn with any manipulation - no matter how small ... "No attempt to turn a white poem into something other than what was born in the mind will work." (Ibid: 93-92)

White poetry has a prose form, but it is different from ordinary prose due to the use of poetic mechanisms such as imagination, artistic expression and song. Shamloo uses a variety of musical techniques such as inner music, side music, etc. The language of his poetry is concise and archaic (archaic) and has unusual theological combinations, which on the one hand is based on the theological style of ancient prose "such as the translation of the Torah and the books of the Old Testament" and on the other hand is influenced by the translation of modern Western poetry. Mojabi says about white poetry:

"In fact, Shamloo replaces the inner music of poetry with the prosodic axis, disrupts the relationship between order and prose, and bases language. He considers words as a molecule that by combining and changing its verbal and spiritual circuits, we go to the line of poetry and 
the wholeness of a piece. In fact, Shamloo, realizing Nima's final message that "revolution in the internal structure of poetry" was something that Nima could not or did not want to do severed the formal and semantic connection with ancient poetry and shattered the form of prosodic poetry, rather than its components. To make a modern mold again - did it; It created new possibilities for form, language, expression, infinite variety, and countless literary forms, and the whole of language, divided by weight into order and prose, was once again exposed to new aesthetic experiences as a single being. It took place in such a way that the poet's approach to the word flew him into the world of poetry, not a complication such as weight and content, instead of the weight of the pronouns that were incidental moving the poem and affecting the final structure of the poem. In white poetry, words were used as a composite cell to serve the movement of poetic concepts and images. In the light of the musical functions of rhythm, harmony and composition, compositions and images and poetic concepts, to architecture The inner part of the poem was so intertwined that that esoteric solidarity integrated and harmonized the outer structure of the poem. The poet's mind moves from the complex layers of the inner structure of the poem in search of the apparent composition, and in fact the "function of the mind" becomes closer to the "inner beauty" of the poem, and the inner sense of the poem that its final composition and structure "Suddenly or gradually in the subconscious mind, the poet translates himself into the words and possibilities of the language of poetry while composing." (Mojabi, ibid .: 82-80)

In sum, white poetry is a poem that in order to become and from potential to actual, invents its own mental and abstract form and feels alienated with everything extra and with every rhyme, and allows no interference or possession, however. The insignificant does not give out what first emanates from the mind. Just as ideas that can be recorded to produce a kind of poetry will never require the creation of a successful poem, this is why white poetry sometimes takes the form of painting and sometimes dance, without any movement in it. To join, sometimes it appears in the form of a classical poem and finds weight and rhyme, and sometimes it appears in the body of philosophical expression. In any case, Sepid Shamloo poetry can not be considered as a continuation of the weight of Persian prose and not a continuation of the weight of Nimai, but it is something that has reached a special form in a long time and with many experiments.

\section{The position of the Third Brotherhood in contemporary Persian poetry}

The Brotherhood is undoubtedly one of the greatest contemporary Persian poets. With his power of expression and extensive knowledge in the field of ancient Persian literature and accurate insight into the current situation of society, he reflects the pains, sufferings and aspirations of the people of his homeland. A lawyer says about him: "Mehdi Akhavan Sales Chavoshi Khan Qawafil regret, anger and hatred, the narrator of forgotten stories and lost dreams. "A poet who is the enemy of deception, obscenity, darkness, lies and evil, and a human being who is a noble friend of decency, light, truth and goodness." (Legal, 1378: 12)

Although he became acquainted with classical poetry at a young age and was able to compose odes and lyric poems, he needed a more appropriate context to express the suppressed hatred of his society so that he could establish a stronger connection with the younger generation of his society. Express a more complete and effective way. He says: "It happened that I saw a certain amount of words remain on the ground in those old ways, it diminishes, it diminishes, it is not said, it really is as it should be said, and it was in this situation. "I became acquainted with Nima's poetry." (Brotherhood, 1997: 15). But at first it seems that the Brotherhood does not like Nima's language and is only looking for a new format that Nima has invented. However, after arriving in Tehran and becoming more familiar with the rules of Nima's poetry, he discovered his style and poetic style. Transformed himself under the influence of Nimai poetry; Of course, the language of the Brotherhood's attitude is fundamentally different from that of Nima, because he adheres to the linguistic and cultural roots of the past. "Nima's language became a valuable example for me, but because my language was different and he had a different upbringing, I learned his style from him and it turned out differently. "My language is Persian, Khorasani." (Same) 
It should be noted that Nima's poetry also had inequalities in structure and problems that the Brotherhood tried to eliminate in its poetry. "The Brotherhood did not limit itself to the mere imitation and nature of Nima's expression, and very soon smoothed the weight and linguistic bumps of Nima's poetry in his poetry ... and by linking the language and literature of yesterday Khorasan and the common language of today's Iran, which culminated in "The poems 'Bonds' and 'Garden' and 'Man and the Composite' can be seen, stamping 'hope' in their own language." (Legal, same)

According to the Brotherhood, Persian poetry forms are always alive and well, and today's poet can use ancient forms as he sings in the form of Nimai poetry; In this regard, he can be considered the first poet who has achieved a detailed analysis of Nimai poetry, especially in terms of weight and format. "In fact, he is a child who has learned his father's experiences and even gone beyond them." (آزند ، 1386: 39

The Brotherhood considers weight to be compatible with Persian poetry and does not want to take it from poetry because it does not consider weightless poetry to be complete poetry. Rhyme, in his view, is a kind of borderline for poetry and does not reject it at all, but claims that poetry without rhyme loses its balance and seems to disintegrate and disintegrate. Arrives. (Rak Ajoudani, 2008: 85)

The Brotherhood is one of the pioneers of contemporary epic-social poetry. His poetic language is a new and unique language; Made by the mind of a creative poet who understands classical Persian poetry well and has been accustomed to it since his youth, and it is this love for the past that has set new horizons before him.

His poetry is rooted in the ancient literature of Iran and tells of his nostalgia for that time, so it has taken on a romantic form both in terms of language and content, so much so that he has been called the poet of defeat epics. In his poetry, the words of colloquial language are easily used alongside the magnificent literary words, and he has created his own distinctive and special language among the poets of his time.

Simply put, the poetic language of the Brotherhood can be considered something between classical and ancient Persian poetry and modern poetry today. "The poetry of the Brotherhood is in fact a bridge between the traditional poetry of yesterday and the modern poetry of today, as if he lived before Nima and is the true link between classical poetry and Nima poetry." (Same: 25)

Ahmad Shamlou, a prominent poet and contemporary poet with the Brotherhood, also considers his language to be something else, and says of his position in contemporary Iranian poetry: "He accepted Nima's form, but used it in a more classical way than Nima. Contemporary poetic style after Nima and even in the same The time of his life was quickly determined, for example, the Brotherhood accepts Nima's offer about weight without learning "pure poetry" from him, in other words, it becomes "contemporary military" in my opinion in the narrative poetry that Nima absolutely "It is not successful, it is success with the Brotherhood." (Langroudi, 1998: 92)

In fact, the poetry of the Brotherhood in all stages of its maturity and dynamism is always on the rise, and this is due to its strong linguistic support and deep knowledge of the original Persian poetry. "The poetry of Omid (Third Brotherhood), Nima and Shamloo, in comparison with the poetry of recent centuries, except for a few exceptional poets, in some of their poems, is a poem that raises the ascending line higher and higher." (Shafi'i Kadkani, 2008: 445)

Not only is he not a true follower of Nima style, but due to his deep understanding of poetry, accurate information about original Persian poetry and its verbal modalities, he has been able to reach a common chapter between the ancient language and the Persian type, but he has been able to promote it as much as possible. Falls. The secret of the success of poets such as Akhavan, Shamloo, Forough Farrokhzad, etc. is that they go beyond the defined lines and poetic contractual frameworks. The Brotherhood, like its master Nima Yoshij, believes in weight, but uses it in a way that makes its poetry fresh and fresh. While emphasizing its dominant role and 
other elements of classical poetry, he emphasizes on avoiding the nature of Nima's words in such a way that in his poems, words and lines cannot be changed and moved, as if each word is exactly in its own place and in The best possible meaning is used; In other words, predicting the structure and prior determination of the course of the poem has replaced Nima's improvisation. By re-reading the myths, he creates another type of Nima poetry that is specific to the Brotherhood itself; However, he always defends Nima and describes his innovations, especially in the two books "Nima's Gift and Meeting" and "Nima's Innovations and Heresies", which have a close and meticulous look at Nima's works and thoughts.

The Brotherhood is one of the pioneers of Iran's new epic-social poetry. Poems, lyric poems, pieces, Masnavi, satires and Brotherhood poems written in the collection of "Organon" (1330) show his detailed studies and extensive knowledge in the field of Persian literature that has dominated his mind and language. His acquaintance with Nima's style and tendency towards it, especially in the collection "Winter" (1335) turns him into an innovative poet and sociologist, and the two collections "The End of Shahnameh" (1338) and "From this Avesta" (1334)) Establishes his position as one of the most important pillars of modern poetry.

Narrative style with emphasis on ancient literature and glorious theology, using elements of Khorasani style and linking it with slang, composition and new illustrations, adherence to Nima poetry in form and music, overcoming the spirit of despair And despair throughout the poem, praise of the manifestations and glories of ancient Iran, doubt and tail are the spoils of Khayyami, hatred and despair of improving the conditions are all considered as features of the Brotherhood poetry; Therefore, he can be considered a historian Randy who, by turning away from today's world, seeks his ideal world in the mental world and the glorious history of his homeland, and when he finds it impossible to achieve it, he admits his socio-historical failure and His descendants sometimes open their mouths to insults and sometimes, with a sneer of despair, take the corner of solitude.

Literary critics divide the poems of the Brotherhood into three periods: "1- The first period begins around the age of twenty and continues until the year 32. During this period, his poetry often had an old style and context and was close to the glorious language. According to Morteza Kakhi, the king of spring poets, seeing his poems, wishes him a good future. 2- The second period of his literary activity begins after August 19, 1932 and continues until around the years 50 and 51. During this period, the Brotherhood seriously deals with Nimai poetry, and with its mastery of classical literature and its interest in the Khorasani language and its roots, combining them with Nimai poetry, creates poems that are rhyming in terms of weight. , Language and content are completely different. It is during this period that political and philosophical themes appear in his poems. His work with language is enviable at this time. The glorious and distinctive language of his poems, along with the new themes he uses, lead to the creation of brilliant and unique poems in contemporary Iranian literature. 3- The third period of the Brotherhood's literary activities continued from the early 50's until the end of his time. One of his most significant works in this period is writing the books "Innovations and Innovations of Nima Yoshij" and "Giving and Meeting Nima". In this first novel, Akhavan describes the form and expression of Nimayi poetry in detail and proves its conformity and compatibility with classical literature, and thus to the consolidation and strength of modern Persian poetry, especially its Nimayi section. "He is taking action." (Alawi, 2005: 94-92)

Jamal Mirsadeghi, a novelist and literary critic, has said about the Third Brotherhood: "I knew the Brotherhood from the Shahnameh. "The Brotherhood's poems gave me a new worldview and insight, and made my attitude towards poetry completely different, and perhaps this was the beginning of my spiritual and inner transformation." (Raadi Azarakhshi, 1370: 39)

Nader Naderpour, a contemporary poet who became closely acquainted with him and his poetry during the first years of the Brotherhood's arrival in Tehran, believes that: In the combination of old poetry and Nimai style and his mourning for the past, Omid created a collection that was unique to him and left a deep impression on his contemporaries and later generations ... His 
poetry is one of the clear sources of poetry today and Its impact on its own generation and the next generation is important. The Brotherhood combined the legacy of poetry and Nimai theory and created an example that created a new innovation without separating from tradition. Brotherhood has its own themes He had Dash, themes of mourning for what was in his heart this mourning sometimes escapes to ancient Iran and sometimes to its own past days, and is basically full of grief and sorrow of that time. These themes have created a special style of the Brotherhood, and for this reason we can see in him both the influence of the past and the influence of modernity and Western schools. "In fact, he was able to achieve a blend of classicism and modernity and create a unique style from it." (Nobakht, 1373: 64)

The Brotherhood believes that it does not seek to create a new style or imitate anyone, and only follows its own feelings and artistic understanding: "I am neither a stylist nor a critic ... I was both inspired by Nima's work and I had my own perception. . In the introduction to winter, I said that I try to connect the nerves and blood vessels and roots healthy and correct language clean and equipped with old facilities and what is related to verbal art to today's feelings and emotions or maybe I have tried from Khorasan to Mazandaran yesterday "I will arrive today." (Ibid: 65)

But Abdolhossein Zarrinkoob does not consider the language of the Brotherhood to be empty, although it sometimes lacks the anomalies and violence that may result from the oscillation between ancestor and joke or old and new, and sees a masculine toughness worthy of the language of a culture. But in his opinion, the form and form of his poem has another hadith: "From him, who praises Nima for giving and meeting all of them, and even for the weak points of Nima's expression, seeks support and justification in the weak points of classical poets, tends to Of course, the features of Nimaee's poetry are not surprising, and although in all such works, he walks in "Rah-e Nima" ... and considers Nima as a leader, he still does not seem to consider him One should be considered a student of the "Nima School" and a "genuine student of Nima Yoshij"; Especially since many people have followed Nima in this way and as soon as they follow this, they have made nothing but the superficial imitations of the form and thought of Western poets.

The fact that the Brotherhood mixes imitation and innovation whenever it gets bored in traditional ways is a privilege for it and shows that it thinks beyond the form and appearance of the essence of poetry and weighs weight, form and language against feeling and thought. "It does not consider itself a barrier to harassment." (Zarrinkoob, 1997: 387-386)

Regarding the language and poetry of the Brotherhood, Dr. Yahaghi says: "The Third Brotherhood should rightly be considered one of the pioneers of epic poetry, which has achieved a new form of epic-social poetry. "The strength and weight of Khorasani poetry, the literary language of the past and his rich imagination in general, along with his references to ancient epic and mythological traditions and his special interest in Ferdowsi's epic language and thought, have distinguished his poetic style." (Yahaghi, 1997: 120)

In general, the Third Brotherhood (M. Omid) can be considered a poet who, with a tendency to revive the old epic and mythological traditions and the strength and weight of Khorasani poetry, has achieved a new narrative style in modern Persian poetry that has made him one of his other contemporary poets. It distinguishes. Few poets can be found who have spoken as much about Iran and its past as he did, so his poetry can be seen as an explicit defense of his homeland's identity and culture and a fierce protest against his race. In the meantime, the Brotherhood has tried to use the principles and foundations of Western literary schools and their purposeful application in their poetry to find a tool to update and make their words more effective and to express their poetic intentions and goals as concretely as possible.

Hamid Mossadegh is one of the poets of the second generation of Nimai poetry, which is related to the moderate branch of this type of poetry in terms of poetic language. have. He was born in 1318 in Shahreza, Isfahan and spent his primary and secondary education there. Then he turned 
to literary activities with people like Mohammad Haghoughi, Bahram Sadeghi and Houshang Golshiri. After receiving his diploma, he went to Tehran and after completing his master's degree in law, he worked as a lawyer. Shortly afterwards, he became a member of the faculty of the Faculty of Law of Allameh Tabatabai University. The end of life remained in this position. Although the last years of Mossadegh's life were devoted more to teaching law and the profession of law than literature and poetry, nevertheless his strong inclination towards literature and rebellious spirit caused him to never distance himself from literature and to connect with literary circles. Keep up with the people of literature.

His first book of poetry was published in 1341 under the title "Darfash Kavian" which was appropriate to the political and social conditions of Iran at that time and is in fact a response to the socio-political needs of the people of that time. When Mossadegh sang Darfash Kavian, "The society of that time was still burning in the heat of the dull and desperate situation after the coup d'état of August 19, 1932, and was very tired and bored and needed the bloating that blew in his half-dead body." And give him a new spirit. "This poem responded precisely to this collective need of the time." (Zarghani, 1387: 636) In this collection, Mossadegh under the influence of Siavash Kasraei in "Arash Kamangir" turns to an epic expression. The use of solid and eloquent language, the extensive use of old words, especially prefix verbs and ancient names, and finally, the use of archeological atmosphere are some of his poetic features in this collection. Mossadegh's second poem was called "Blue, Gray, Black" which was published in 1964.

This poem is one of the most beautiful poems of Mossadegh, which has a lyrical and at the same time socio-political atmosphere. The beginning of this pink effect is completely lyrical and after that different emotions and perspectives It examines and ends with an invitation to fight. This book of poetry, both from a romantic and a social point of view, expresses the poet's feeling of homesickness and deep nostalgia for the fading of human emotions. The main theme of this system is the call for solidarity in the era of separations and failures. The evolution of poetry from an individual perspective to social insight shows the symbolic form of the social, political and literary transition of the poet's society. The poet's tendency from individual romanticism to social symbolism is also in line with the poet's movement from one attitude to another, which have appeared in his poetic perspective; In this sense, Mossadegh should be considered a poet who has reached a socialist vision through love and romantic lyricism. (Rok Roozbeh, 1389: 391)

Mossadegh is one of the committed, revolutionary and populist poets for whom poetry is the rule of life. Apart from his half-hearted and lyrical tendencies, his works are full of political and social allusions. Love, youthful passion, longing for the past, freedom, patriotism and justice are the main themes of his poetry, but undoubtedly the most prominent feature of his poetry is its simplicity, mentality and fluid intimacy. The easy and restrained language that Mossadegh uses in his poems, while being simple and unaffected, never takes on an imitative color. The descriptive, metaphorical form and all the understanding of his words make his poems easily penetrate and remain in the public mind. Ali Babachahi - a contemporary poet - considers this simplicity and mentality in Mossadegh's works as a special literary and poetic genre that was confronted with the complex flow of contemporary poetry. He believes: "The simplicity that exists in Mossadegh's poetry is based on the element of emotion and a kind of isolation. This is where, if we have the two titles "simple avant-garde poetry" (leading) and "ordinary ordinary poetry", Mossadegh's poetry for any reason - of course, as he wanted - can not be found next to "simple poetry Avant-garde "contract; But in any case, Mossadegh's poetry, because it was based on slogans in specific political periods of Iran before the revolution and on the nature of the struggle, somehow fell into the nature of a section of society that did not deal with poetry professionally and as a lieless poem. It was considered, it was far from artificial and it had the characteristics of messaging, it found its way among the people and the society. Mossadegh was one of the poets who remained faithful to the rules and principles of prose of modern poetry. 
"He did not want to continue the other or superior aspects of Nima's poetry, and the kind language of Mossadegh's poetry made people unfamiliar with it even today." (Abu Mahboob, 1387: 186)

In terms of the use of words and combinations, his poetry has always kept its simple form and is not subject to a specific linguistic determination. He uses all his everyday lexical capacities to express his poetic intentions, so he should be considered more of a semantic poet than a word processor who has made the word a tool to convey the desired meaning as well as possible. Among the other factors that make his poetry simple is the folklore that exists in his words. Following Nima, Hamid Mossadegh did not limit himself to the use of formal words and practical elements, and in addition to using the language of ancient official etiquette, he also included various elements of colloquial language in his poetry and tried to simplify the language of poetry by giving them a sensory burden. And bringing it closer to the minds and tongues of the people. This practice is mainly done in his poetry through the use of slang terms, proverbs and allusions common among the common people, common colloquial words, allusions to folk tales, beliefs and customs, local words, and so on. The culmination of the use of these elements can be seen in his lyrical and romantic poems, which are especially evident in the last collection of "Red Lion".

In his poems, one can always see traces of symbolism and symbolism. By depicting the social and political conditions prevailing in society, he tries to express collective tensions and concerns in symbolic language. Mystical, romantic, national, religious, etc. myths, which are found in abundance in his poems, often indicate his interest in the national-patriotic culture of his land and express the commitment he feels towards his people.

Mossadegh is also considered a naturalist poet. The natural elements in his poetry often take the form of social symbols; "In fact, his fantasy elements have three aspects: symbolism, naturalism and mythology, all of which have social and romantic themes. Like all human actions, the words and elements of expression of every poet are born of his desire. ... One of the changes that Nimai's poetry has created is the strengthening and expansion of the vertical axis of imagination. "The poem" Darfash Kavian "is a story in a memory, this storytelling of the poem has made and established the vertical axis of the poem." (Same: 140)

Intimacy and awareness in poetry, deep perception of objects and environmental conditions and a deep understanding of the frequencies of time are the most important factors for the survival and evolution of Hamid Mossadegh's work. He speaks in a simple, unadulterated and sincere way, so much so that the reader, accompanied by him, suddenly feels himself in a completely intimate, oriental and indigenous poetic environment and is filled with the purest human emotions.

He is a poet who lives with poetry, cries, falls in love, knows himself and introduces himself to people. Therefore, Mossadegh can be indebted to poetry and poetry can be called indebted to Mossadegh. His poetry is a kind of romance that depicts beyond love. He is a poet of sorrow and pain of love and expresses his grief over the separation of the beloved in his poems through the lens of nostalgia. His romantic and romantic poetry is accompanied by childish and sincere nostalgia, and despite his attention to the present and current issues, he has a mostly regretful look at the past. He never sacrifices content The reed does not take shape and offers a new content to the reader in each poem.

But the main feature of his poetry is the clever combination of love and politics, where he uses love poetry as a basis for expressing political ideas and critique of the government of the time, and despite the use of archaic language in his poetry, he uses simple and smooth prose to express his thoughts. Chews.

According to Mossadegh, poetry creates a dual relationship: one is the poet's relationship with himself and his inner self, and the other is his relationship with the reader and the people. In this 
case, poetry will only be able to communicate with people if it comes from the heart and also requires time. Despite having political tendencies, he avoids degrading his poetry to artificial and factional slogans, and considers it to be a destruction of the work of art.

Despite his novelty, his poetry remains faithful to the rules and principles of the new poetry. He does not want to be seen as a follow-up to the superior style of Nima poetry; Therefore, unlike Nima, he always tries to use a gentle and sincere expression in his poems. Mossadegh himself considers the reason for the attractive simplicity and intimacy of his poetry in this sincere treatment of people and commitment to language unaffected and free from beliefs that are not understandable to people. In his opinion, the use of verbal and spiritual restraints in an extreme way prevents most people from being able to establish a natural relationship with poetry, and this failure of the poet to establish a relationship between the reader and his poetry is a reason for his weak relationship with poetry. I am his inner self.

Mansour Oji - a modern contemporary poet - believes that if we divide poets into two groups of contentists and formalists for whom pure poetry is important. Hamid Mossadegh is in the first group, that is, he wants to present a new subject to the reader in each poem. He was one of the social poets who was noticed in the 40's with his two books "Darfash Kaviani" and "Blue, Gray, Black". Mossadegh has remained faithful to the content in his work until the end of his life; Of course, unlike some poets who chose the easier way, he did not leave weight out of his works and remained faithful to weight for the rest of his life. It can be said that his poetry turned the protest dimension into a melodic and rhythmic dimension. (Same rack: 141)

Mossadegh's poetry has a fluent structure and syntax and, unlike some poets, has no specific theological beliefs. Most of his fame is due to this language, which is devoid of verbal and spiritual techniques. He is less influenced by a particular poet; Of course, he had a special devotion to Siavash Kasraei and sometimes he was subconsciously influenced in some of his poems by Shamloo, Akhavan Sales and Fereydoon Moshiri, but in general, his poetic language is so simple and pure that it is not possible to accept a certain color by He was conceived from the poetry of another poet.

Mossadegh is a poet who knows his socio-political tendencies well and clearly shows his commitment to them. The structure of his poems has been carefully designed and tells of a kind of transition in society and literature of the poet's time. Most of his works begin with a romantic construction and, in their natural course, change their nature to a political construction and take on a social dimension. His poem is in fact a cry that does not smell of blood, but a loud voice of rebellion can be heard from it. Although his poetry has a romantic basis - both in the individual and in the social dimension - it is always associated with a kind of realism; In fact, his poetry is a kind of intersection of idealism and realism. He always speaks of his ideals. Social, human ideals, etc. This is why the return to the nostalgic and desirable feeling of the past is very visible in his poetry. He does not want to bow down to the existing reality; Therefore, he is constantly in conflict with the world around him so that he does not interpret the facts according to his ideals. Memory, desire, love and strife are the main themes in the formation of Mossadegh's emotional and intellectual system; Hence, perhaps despair and rebellion are less seen in his works than in the works of the Brotherhood and Shamloo.

Nature is not used in Mossadegh's poetry in its naturalistic sense, because in this case, nature refers to human biological and genetic algebras, while Mossadegh does not believe in human algebra and always seeks to break it. If nature is mentioned in his poem, it is in the same romantic sense, ie mountain, plain, forest, sea, sky, etc., a general concept that Jean-Jacques Rousseau also acknowledges. Naturalism in Mossadegh's poetry is mostly due to expressing disgust with the city and modern civilization, and except in the two collections "Red Lion" and "Darfash Kavian", it has a colorful appearance in the rest of his works. Of course, this attitude is due to the same natural desire of the urban man who is tired of the city and the mechanism that seeks a refuge away from the hustle and bustle of the city to soothe his restless and disturbed soul for a moment. 
Finally, Hamid Mossadegh should be considered a social and political poet who always has the concern of Iran, freedom, love and equality in his poetry. Although he has similarities and similarities with others in some general issues, he always pursues his own artistic style: "Lack of abandoned and unfamiliar words and complex terms, use of common and common allusions, use of traditional combinations, lack of insistence" Using verbal and artistic arrays. "... is one of the stylistic features of Mossadegh's poetry." (Abu Mahboob, ibid .: 99) These characteristics have also caused his words to be very popular and accepted among everyone and make him one of the most enduring contemporary Persian poets.

\section{Romanticism in the poetry of Hamid Mossadegh}

Romanticism is a philosophical-literary school whose most prominent features emphasize concepts such as norm-breaking, innovation, anti-tradition, ambition, fantasy, loneliness, Despair is literary despair and resurrection "(Rostami, 2003: 7)

Before rheumatism, emotions in the same ancient forms could be offered to the audience; Therefore, the real beginning of rheumatism should be considered from the time when transformational and daring writers created a new way of expressing their feelings and emotional tendencies and individual attitudes and used it ruthlessly in their literary works.

But the beginning of contemporary romanticism in Iran should be considered a "myth" with Nima Yoshij and his famous poem; Although Nima himself continues to work more towards social symbolism; However, others such as Dr. Parviz Natel Khanlari, Golchin Gilani and Fereydoun Tolli took the lead in this direction under the influence of Nimai molds and created works in this direction. Following that, other poets followed their path and tried to promote it as much as possible, which eventually led to the emergence of poets with style and innovation such as Nader Naderpour, Nusrat Rahmani and .... Hamid Mossadegh is undoubtedly one of the greatest novelists of romanticism who experimented in this field. He should be considered as one of the poets with multiple tendencies and approaches who have included different types of poetry such as epic, national, political, romantic and lyrical in his collection of poems and have studied them comprehensively. For example: from one point of view, he is considered an epic, libertarian and political poet, which can be seen in his very first collection of poems entitled "Darfash Kaviani". In his next two works, "Blue, Gray, Black" and "Through the Wind", there is an enlightened, social and to some extent professional poet who reacts to the events around him and feels responsible. This approach takes a more tangible form in the last three collections, namely, "From Separations", "Years of Patience" and "Red Lion", which of course does not mean changing the poet's general attitude from epic to lyrical or vice versa, but means that he achieves It is a combined way of expressing both literary genres.

\section{Reflection of the components of romanticism in Hamid Mossadegh's poetry}

At a glance, romanticism is introduced in Mossadegh's poetry in both its individual and social dimensions. He has used both of these branches in order to better express his poetic intentions and concepts. "Darfash Kaviani" is Mossadegh's first book of poetry, which was published in 1341. The symbols of this book of poetry are mythical characters in which the features of social romanticism are very prominent, but in the book of poetry "Blue, Gray, Black" published in 1342 , unlike the previous collection, this romanticism is individual. Which overcomes social romanticism; At the end of the day, though, it combines two social and emotional features. The most important individual symbols in this collection are the window, the dream, my sister's child and the night, the wind, and so on. "In the Way of the Wind" is the third book of poetry by Hamid Mossadegh, which was published in 1347. In this office, we again see the superiority of the features of individual romanticism over social romanticism. Keywords in this collection include wind, Zayandehrud, spring, river, tree, elm, fish, etc. In Hamid Mossadegh's fourth book of poetry "From Separations" in 1979, the poet, while expressing oneness with nature, used frequently used words such as mint, rain, wine and spring, wave, sunrise, window, fence, honesty, etc. Top hired. In this office, too, we see the dominance of individual romanticism 
throughout the poetic space. "Years of Patience" is another book that was published in 1982 and includes two books, "Spring of Love" and "Signs". In these two books, natural signs can still be seen in abundance, with the difference that in the first book, individual romanticism prevails over social, but in the second book, we see the dominance of social romanticism over the individual. The most widely used symbols of this office are: Kaveh, Siavash, Per, Parvaz, Shab, Sang, etc. His last book of poetry was called "Red Lion" in 1997 and was written with the domination of individual romanticism; However, there are traces of social romanticism in it. One of the prominent poetic symbols of this collection is night, wind, tree, willow, desert, mirror and stone.

\section{1- Freedom}

Romanticism is a revolutionary and cultural movement that, for the first time since the Middle Ages, freed the artist from the shackles of tradition. This school promoted freedom of expression and belief in various aspects of philosophy, culture, literature and art by breaking all classical rules and guidelines. In fact, freedom and libertarianism in all spheres form the basis of all romantic views. According to the Romantics, literature is not an attitude to limit love and freedom and can include all aspects of life, both good and bad, ugly and beautiful. The poet must be able to write poetry free from the cumbersome traditions of the past and comment on political and social issues.

This libertarian view gradually moved away from the individual form and extended to social issues and attracted the attention of poets to the political issues of its time so that addressing the situation of society has become their main and daily concern. , Over time, changed its face to a revolutionary attitude. In the romantic view, individual and collective freedom are one and the violation of individual freedom follows the violation of collective freedom; Therefore, the existence of a force that can disrupt the existing wrong order and cause the elimination of all these disorders seems inevitable.

In Hamid Mossadegh's poetry, the category of freedom is considered more than its social aspect; Of course, as mentioned earlier, this trend does not have the same frequency in his various collections.

Occurrence of political events such as 28 August 1332, caused frustration Gay poets from changing the existing conditions and reacting negatively to it. Hamid Mossadegh, like other committed poets and writers of his time, feels responsible for the socio-political situation of his society; Therefore, he reacts to the injustices and inequalities that are taking place in his country and calls on the people to show solidarity and revolt in order to realize their rights.

«... / The word must be said! / The pain must be said! / It is not about my love and your kind / It is about the disintegration of friendship, / and the futility of the happy idea of love / Familiarity with passion! / And separation with pain? / And sitting in your forgetfulness / or drowning in pride ?! / My chest is a mirror, / With the dust of sorrow / You remove the dust with a smile from this mirror / Empty nests fill my hands / The chicken in your hands fills. / Oh, do not let my hands forget the trust it has in your hands / Oh, do not let the white birds in your hand, / Let my loving hand be cold and exhausted. / What am I saying, oh ... / What forgetfulness with you now; / What sits with me now, the blackouts. "You do not think that I am silent, / there is a proof of my forgetfulness / if I get up / you if you get up / everyone gets up." (Mossadegh, 1381: 69)

In this poem, Mossadegh calls the people to stand up and confront the enemy with an epic tone and repeating the word "get up" and considers silence and indifference as an unforgivable sin that means nothing but surrendering to oppression and destruction.

He is a freedom-loving poet and uses every opportunity to express his oppressive and liberating ideas, and by complaining about the lack of freedom and love in the barren desert of his land, he intends to motivate people to rise and move until freedom is achieved. N. 
"Let 's go / Where is the song of love and the breeze of freedom / In this desert I do not see the sign of freedom / The sign of happiness / I am heartbroken by these harsh methods / Let' s go / Blessed to rise and go / Towards freedom." (Ibid: 221)

"I passed through the hard fence / On the other side of the fence is happiness / On the other side of the fence / There is the passion of liberation and freedom" (Ibid: 200)

Unlike Shamloo and the Brotherhood, he never sees the future as completely black, but always leaves a window of hope beyond himself and the wall of tyranny for himself and his people. According to him, the only way to achieve liberation is stability and continuity in the struggle and maximum participation of the people in this regard.

"Stand up / The palms of your hands should hold the sword / Your archers should shoot in the bows / You should have a firm and persistent determination now" (Ibid: 33)

This poem reflects well the romantic views, especially the social romanticism of the poet. By constantly repeating the word "stand up", he calls on the people to rise up and fight against the enemy and considers submitting to humiliation as a great betrayal and a sign of weakness and lack of commitment to national and human ideals., With a revolutionary attitude, calls the people to revolt and armed uprising until they achieve freedom.

"Let's go back to the city / see with our own eyes / that the children with machine guns in the alley / emptied their minds in the mirror / with a push to the trigger / thousands of people / and threw the enemy's lot on the ground"

In some cases, he sympathizes with the deprived class of his society and reflects their pain and suffering in the most obvious way possible.

"O you who are so upset / O hard cold stone / I am your sympathizer / I also cry in your calamity" (Ibid: 486)

In the meantime, his sympathy is sometimes accompanied by a call for revolt and uprising in order to achieve justice and equality: "Now my son-in-law's city is being looted / put the cup in it / and take the ax / why? "/ The root of this poisonous growth / needs an ax." (Ibid: 368) And sometimes this invitation leads to nothing but deep despair and disappointment for the poet, and what is left is only the feeling of sympathy: "Dear friend / We never planted the wind to reap the storm / We sowed the seeds / We sowed the effort to grow from the ground / But the night when the harvest was hot / - In that pleasant feast - / Suddenly the bastards! / What can I say ... / That's it! " (Ibid: 606)

He, who has the pain of the homeland, finds a way to seek help from mythical and epic characters to express the issues related to it and his freedom-seeking ideals, and by mentioning their bravery, freedom and chivalry, he encourages others to continue on their path. And the plaintiff invites the demands on their rights, and in this regard, he ignores the judgment and the destiny and sees no more than an excuse "... who says / the judgment of heaven is this and will not change? / Judgment is not heavenly / If a man rises / And you fight with my heart's / A tyrant and worthless / Why will he not bow to the determination of men and brave men? (Ibid: 42)

The use of personalities who have always been a symbol of freedom-seeking and struggle against oppressors throughout Iran's history is mainly a pretext in Mossadegh's hand to express his political and social intentions and to stimulate public opinion in order to create a pervasive current.

"Beside Kaveh blacksmith's kiln / He shed tears of joy on his finger / The one who said:" Farry wind and Homayoun wind / You are determined / O free people / Come back to Mehr / ... / Kaveh's gaze An infinite eagle walked away / His heart and soul were with Ahura at that time / 
He raised his hands to the sky / The companions did the same / He prayed with the God of the covenant of Mitra ... "(Ibid: 49-41)

Kaveh has always been a symbol of freedom and patriotism in Persian literature, unlike Aji Dahak, who is presented as an oppressive and hated figure. Mossadegh also makes good use of this in his poetry to create a meaningful confrontation for his audience.

"To the palace of Andar / which was surrounded by towers and fortifications / To the heart of this roaring sea was the inverted / Sitting dragon of the demon Xu / On his bed awake / lest anyone wake up / His lips thirsty It was blood "(same)

The poet encourages the free and patriotic Iranians to persevere and resist the ridiculers of their time and promises them freedom and victory in the shadow of perseverance:

"Now you, all Kavehs, get up / and fight with the Damavand detachment / that forever / to the root of oppression and oppression / to strike axes / and bury the bottom / the body of Zahak / the symbol of dormant oppression, to the chest of the soil (Ibid: 349)

Elsewhere, referring to the stories of "Dara and Iskander" and "Khosrow and Shirin", Mossadegh uses them as an excuse to create another national work and express his sociopolitical goals:

"Close the bud is an adjective of the lips, it is a bloody time / What is the purpose of flowers? Autumn poisons are / Sohrab Hasrat Ayam, the result of Farhad / Sweet sweet wine is in Parviz's mouth / ... / The world smells hot from Lalehzar / To the river How terrible is the smoke of blood / The country is always ruined by Alexander / The kingdom of Jam is always under the control of Genghis "(Ibid: 370)

Here, the poet depicts the suffocation and lack of freedom in his land by using tangible and quick-moving symbols, allusions and similes.

Elsewhere, Mossadegh describes the events before the coup d'état of August 19, 1943 and the prevailing atmosphere in a metaphorical and virtual way: "Gypsy wind, oh wind! / How cruel you are, / You stripped the leafy branches of the trees; / And you destroyed the world with the poisons of your breath / Why did your gypsy wind howl / still very broken Annan / Poison smashed on the ground, you passed everywhere "(Ibid: 80)

By presenting a picture of the ruthless onslaught of gypsy winds on trees and stripping them of every leaf and load, Mossadegh likens the poisonous and howling breath of the wind to the broken horses of Annan, destroying the soil. With this metaphorical expression, the poet has tried to break the tyrants of his time into the wind and horses of Annan, and to make people look like naked trees and his land like a ruined garden, thus depicting the dire situation of society.

"My heart burns / That they filled the canaries / that broke the swallows' feathers and the pigeons / ... / And what a great hope led to futility" (Ibid: 71-70)

Here, the poet expresses his regret for the futility of his hopes and aspirations with an artistic expression. 


\section{References}

1) Shamisa, Sirus (1373), Poetry Stylistics, Ferdows Publishing, Tehran, Second Edition.

2) Mojabi, Javad (2002), The Mirror of the Morning, Green Season Publishing, Tehran.

3) Plekhanov, Georgi (1979) on Literature, translated by Manouchehr Hezarkhani, Ronagh Publications, Tehran, first edition

4) Ashouri, Dariush, (1998) Poetry and Thought, Markaz Publishing, Tehran, first edition

5) - Saheb Ekhtiari, Behrouz and Bagherzadeh, Hamid Reza (2002), Ahmad Shamloo, poet of nights and romances, Helmand Publications, Tehran, first edition.

6) Legal, Mohammad (1998) Poetry of our time 2, Mehdi Akhavan Sales, Negah Publications, Tehran, fifth edition

7) Azhand, Yaghoub, (1363) Literary modernity in the constitutional period, published by the Institute for Research and Development of Humanities, Tehran, second edition.

8) Langroudi, Shams (Mohammad Taghi Javaheri Gilani) (1998), Analytical History of New Poetry, four volumes, Markaz Publishing, Tehran, second edition.

9) Shafiee Kadkani, Mohammad Reza (1980), Periods of Persian poetry from constitutionalism to the fall of the monarchy, Toos Publications, Tehran, first edition.

10) Alavi Moghadam, Mahyar (1998), Stylistics of Persian poetry (from Roudaki to Shamloo), Niloufar Publications, Tehran, first edition.

11) Mossadegh, Hamid (2002), Collection of poems by Hamid Mossadegh (until liberation), Negah Publishing, Tehran, 11th edition.

12) Nobakht, Iraj (1372), Persian poetry and prose in the social field, Rabi Publishing, Tehran.

13) Rostami, Fereshteh va Keshavarz, Massoud (2003) Romanticism in Forough Farrokhzad's Poems, Nawa Danesh Publishing, Tehran.

14) Abu Mahboob, Ahmad, (2008) In the mood of the wind (in the life and poetry of Hamid Mossadegh), Third Edition, Tehran, second edition. 